\title{
Variables Explaining Bank Stock Prices
}

\author{
Jimmy D. Moss, Lamar University, USA
}

Gisele J. Moss, Lamar University, USA

\begin{abstract}
The purpose of this study is to examine the relationship between an index of bank common stock prices and a variety of explanatory variables including interest rates on Treasury securities of various maturities and other economic variables. We also examine the relationship between the term structure of interest rates and bank stock prices. A sample of week ending values of the bank stock index is used as a proxy for the bank industry. The weekly closing interest rates for the 13week Treasury bill, 5-year Treasury note, 10-year Treasury note and the 30-year Treasury bond are used in the study. Other data used were the U.S. dollar index, the CRB index, the price of gold, the S\&P500 stock index, the VIX stock market volatility index and a measure of the yield curve. Data was taken from January 1998 through November 2009. Therefore, a total of approximately 620 cases of weekly observations are included in the study. In order to study the effects of term structure of interest rates on bank stock prices, we take the difference between the 10-year Note and the 13-week Bill. All variables are converted to a stationary series by taking first differences of each series. Multiple linear regression is then used to study the variables that can explain bank stock prices. A stepwise procedure was used to identify those variables with the strongest relationships in a multi-variable equation. Three independent variables were found with an $R$-squared of 0.619. The results of this study corroborate previous studies and have practical implications for investors and for bank managers.
\end{abstract}

Keywords: bank stock prices, interest rates, multiple regression

\section{INTRODUCTION}

$\mathscr{J}$

he purpose of this study is to examine the relationship between an index of bank common stocks and various macroeconomic variables including short, intermediate, and long-term interest rates. We further examine the relationship between the term structure of interest rates and bank stock prices. Previous studies indicate that bank stocks are sensitive to interest rates. However, many of those studies are dated, whereas, this study uses current data that includes the time period of the recent financial crisis.

\section{LITERATURE REVIEW}

There have been several studies of the interest rate sensitivity of bank common stocks. Lynge and Zumwalt (1980) found significant interest rate sensitivity of commercial bank common stocks using both long and short-term interest rate indices. Booth and Officer (1985) found bank stock returns were sensitive to interest rates. They were able to show that the sensitivity was not found in non-financial institution portfolios. Flannery and James (1984) also found significant interest rate sensitivity by financial institutions.

Akella and Chen (1990) found that bank stock returns were sensitive to holding period returns on long-term government securities. Bae (1990) found that a commercial bank sample showed significant sensitivity to current and unanticipated interest rate changes. Ewing, Payne, and Forbes (1998) found that increases in the prime lending rate and decreases in one-month $\mathrm{CD}$ deposit rate tend to raise the value of bank stocks. Further, Yin, Yang, and Handorf (2007) found that bank stock prices were inversely related to changes in the federal funds rate. 


\section{METHODOLOGY}

A sample of week ending values of a bank stock index is used as a proxy for the bank industry. The index (known as the BKX Index) is composed of 24 geographically diverse exchange-listed and over-the-counter stocks representing national money center banks and leading regional institutions. The BKX Index was created in 1962 and calculated retroactively to 1947. Index options on the BKX Index are routinely traded on the Philadelphia Stock Exchange.

The weekly closing interest rates for the 13-week Treasury bill, the 5 year Treasury note, the 10-year Treasury note, and the 30-year Treasury bond were used in the study. Data was taken from January 1997 through November 2009. During this time period, there was both a rising and a falling stock market. There was also a period of relatively high interest rates and a period of falling rates. Therefore, the results should be robust to a variety of market trends. A total of approximately 620 cases of weekly observations are included in the study.

Independent variables other than interest rate variables used in the study include the price of gold, the value of the U.S. dollar (as measured by the Finex spot index consisting of a basket of foreign currencies), the S\&P500 stock index, the Commodity Research Bureau (CRB) index of commodity prices, and the VIX (a measure of stock market volatility). In order to study the effects of the term structure of interest rates on bank stock prices, we took the difference between the yields on the 10-year note and the 13-week bill.

One of the common problems associated with using time series economic data is that the series is often non stationary. Since regression techniques require that data in a series be normally distributed, it is necessary to convert the non stationary series into a stationary one. Tests were first run to determine the stationarity of each series using the Augmented Dickey Fuller test for a unit root. If the series has a unit root, the series can be made stationary by taking first differences of the data. It was found that each series was non stationary with a unit root. Therefore, first differences of the data were computed and used in the regression analysis. Stepwise regression was used to find the best set of variables to explain changes in bank stock prices.

\section{FINDINGS}

Table 1 shows the results of the regression analysis of the BKX on all variables used in the study. All possible independent variables were tested to find which best explain bank stock prices. Stepwise regression then eliminates, one by one, those variables that do not explain the dependent variable. This process leaves only those independent variables in the equation which, as a group, best explain the dependent variable. Three independent variables were found that best explain bank stock prices. Those variables were the S\&P500 stock index, Treasury bill yields, and the CRB index. The adjusted R-squared for the equation was 0.619 and the Durbin Watson statistic was 2.148. Values close to 2.0 indicate that there is no autocorrelation in the equation.

Table 1 - Results of the regression of the first differences of BKX on various economic variables

\begin{tabular}{|c|c|c|c|c|c|}
\hline $\begin{array}{l}\text { Dependent } \\
\text { DBKX }\end{array}$ & $\begin{array}{l}\text { Constant } \\
-.076 \\
(-.946)\end{array}$ & $\begin{array}{l}\text { Independent } \\
\text { DS } \\
0.083 \\
(31.457) \\
\\
\text { DTBL } \\
-2.563 \\
(-4.182) \\
\\
\text { DCRB } \\
-0.049 \\
(-3.920)\end{array}$ & $\begin{array}{l}\text { P-value } \\
0.000\end{array}$ & $\begin{array}{l}\text { Adj. R Sq. } \\
.619\end{array}$ & $\begin{array}{l}\text { DW } \\
2.148\end{array}$ \\
\hline
\end{tabular}

Note: Number of observations used in the regression $=616$. T-statistics are shown in parentheses immediately below the unstandardized coefficient for the independent variables and the constant. 
Where:

DBKX $=$ first difference of the BKX index

DS $=$ first difference of the SP500 stock index

DCRB $=$ first difference of the CRB commodities index

$\mathrm{DTBL}=$ first difference of the 13 week Treasury bill

Significant correlation between independent variables is known to be one of the primary causes of multicollinearity. One way to detect multicollinearity among the independent variables is to check the correlation among the variables. Table 2 shows the correlation coefficients for all the variables in the final regression equation. A correlation coefficient of 0.70 or higher between any two independent variables is often an indication of possible multicollinearity problems. However, the results of this study show that the correlations are well below 0.70 and sufficiently low enough to rule out any multicollinearity among the independent variables.

Table 2 - Correlation coefficients for the variables used in the multiple regression equation.

\begin{tabular}{lllll}
\hline & DBKX & DS & DTBL & DCRB \\
DBKX & 1.0 & $.774 * *$ & -.011 & .046 \\
DS & $.774 * *$ & 1.0 & $.129 * *$ & $.192 * *$ \\
DTBL & -.011 & $.129 * *$ & 1.0 & $.092 *$ \\
DCRB & .046 & $.192 * *$ & $.092 *$ & 1.0 \\
\hline
\end{tabular}

Note: Number of observations used in the regression $=617$.

** Correlation is significant at the .01 level.

* Correlation is significant at the .05 level.

Where:

DBKX $=$ first difference of the BKX index

DS $=$ first difference of the SP500 stock index

DCRB $=$ first difference of the CRB commodities index

$\mathrm{DTBL}=$ first difference of the 13 week Treasury bill

Another more direct test for multicollinearity is to consult VIF (variance inflation factor) and tolerance measures which detect multicollinearity among the independent variables. Table 3 shows the results of these measures. Tolerance values below 0.10 or VIF values above 10 indicate the presence of multicollinearity. Because all the values in this table are near 1.0, multicollinearity is not a problem in this equation.

Table 3 - Collinearity statistics for independent variables used in the study.

\begin{tabular}{lcc}
\hline DS & Tolerance & VIF \\
DTBL & 0.951 & 1.052 \\
& 0.979 & 1.022 \\
DCRB & 0.959 & 1.043 \\
\hline
\end{tabular}

Note: Tolerance values below 0.10 or VIF values above 10 indicate the presence of multicollinearity. 


\section{CONCLUSIONS}

The results of this study corroborate those from previous studies, i.e. bank stock prices are sensitive to changes in interest rates. Further, our results have practical implications for investors and for bank managers. Investors who believe that interest rates will be moving higher (lower) might do well to underweight (overweight) their portfolios with bank stocks. Bank managers who believe that interest rates have peaked might find this to be a good time to repurchase shares of their bank's common stock if excess funds are available. If they believe that interest rates have bottomed, they might do well to issue new shares of common stock as a way of obtaining additional long-term financing.

\section{AUTHOR INFORMATION}

Dr. Jimmy D. Moss, D.B.A., is a Professor of Finance and Chair of the Economics and Finance Department at Lamar University. He obtained a D.B.A. at Mississippi State University in 1986. He has taught at Lamar University for 24 years. His research interests include efficient markets, investments, and finance education.

Dr. Gisele J. Moss, Ph.D., CPA, is an Associate Professor of Accounting and the Pat Wheat Faculty Scholar in Business at Lamar University. She received her Ph.D. from Louisiana State University. Prior to her academic career, she spent a number of years in industry specializing in corporate reporting. Her research interests include financial/managerial reporting issues and accounting education.

\section{REFERENCES}

1. Akella, S. R., and S. Chen. 1990. "Interest Rate Sensitivity of Bank Stock Returns: Specification Effects and Structural Changes." The Journal of Financial Research (13): 147-154.

2. Bae, S. C. "Interest Rate Changes and Common Stock Returns of Financial Institutions: Revisited." 1990. The Journal of Financial Research (13): 71-79.

3. Booth, J. R. and D. T. Officer. 1985. "Expectations, Interest Rates, and Commercial Bank Stock." The Journal of Financial Research (8): 51-58.

4. Ewing, Bradley T., et.al. 1998. "Co-movements of Prime Rate, CD Rate, and the S\&P Financial Stock Index." The Journal of Financial Research (XXI): 469-482.

5. Flannery, M. J., and C. M. James. 1984. "The Effect of Interest Rate Changes on the Common Stock Returns of Financial Institutions." Journal of Finance (September): 1141-1153.

6. Kohers, T., and R. Nagy. 1991. "An Examination of the Interest Rate Sensitivity of Commercial Bank Stock." Review of Financial Economics (1): 23-34.

7. Lynge, M. J., and J. J. Zumwalt. 1980. "An Empirical Study of the Interest Rate Sensitivity of Commercial Bank Returns: A Multi-Index Approach.” Journal of Financial and Quantitative Analysis (September): 731-742.

8. $\quad$ Rose, Peter S., and James Kolari. 1995. Financial_Institutions. $5^{\text {th }}$ Edition. Chicago, Ill.: Irwin Publishing Co.

9. Seiler, Michael J. 2004. Performing Financial Studies: A Methodological Cookbook. Upper Saddle River, N.J., Pearson Education, Inc.

10. Van Horne, James C. 1994. Financial_Market Rates and Flows. $4^{\text {th }}$ Edition. Englewood Cliffs, N.J.: Prentice Hall Co.

11. Yin, Haiyan; Yang, Jiawen; and Handorf, William. 2007. "Interest Rates and the Value of Bank Equity." Bank Accounting and Finance (October-November): 11-16. 